\title{
Utilization of Vessel Automatic Identification System (AIS) to Estimate the Emission of Air Pollutant from Merchant Vessels in the Port of Kaohsiung
}

\author{
Ta-Kang Liu*, Yung-Sheng Chen, Yen-Tin Chen \\ Institute of Ocean Technology and Marine Affairs, National Cheng Kung University, Taiwan 70101, Taiwan
}

\begin{abstract}
Vessel-source air pollution may have a major impact on human health and the marine environment. In this study, a method based on vessel activity intensity was adopted to estimate the emission of air pollutants generated by the consumption of fuel oils from merchant vessels in the Port of Kaohsiung. The vessel activities were determined by using the vessel automatic identification system (AIS) to track vessel traffic and position and to calculate the corresponding emission of air pollutants. It was found that container ships, bulk carriers, and oil tankers, emitted approximately $90 \%$ of the total air pollutants. The emissions of $\mathrm{SO}_{2}$ and $\mathrm{NOx}$ accounted for $43 \%$ and $23 \%$, respectively, when compared to the land-based source emission from the city of Kaohsiung. Management strategies were explored that market-based tools are recommended for the mitigation of vessel-source air pollution along with mandatory utilization of low sulfur fuels.
\end{abstract}

Keywords: Vessel activity; Sulfur dioxide; Vessel-source pollution; Automatic identification system (AIS); Low sulfur oil; Shore power facilities.

\section{INTRODUCTION}

Maritime shipping is currently the most reliable form of cargo transport for global industrial trade. Marine navigational transportation requires a great deal of fuel oils and consequently emits large amounts of air pollutants, including diesel exhaust, particulate matter (PM), volatile organic compounds (VOCs), nitrogen oxides $\left(\mathrm{NO}_{\mathrm{x}}\right)$, ozone, and sulfur dioxide $\left(\mathrm{SO}_{2}\right)$ (Im et al., 2005; Lister et al., 2015; $\mathrm{Xu}$ et al., 2017). Vessel-source air pollution may have a major impact on the marine environment and ecosystem. In order to prevent the pollution caused by maritime vessels, the International Maritime Organization (IMO) adopted the International Convention for the Prevention of Pollution from Ships (MARPOL), and in 1997, Annex VI was added to MARPOL $73 / 78$ to regulate the air pollution emitted by maritime vessels (IMO, 2010; Blatcher et al., 2013; Butterfield et al., 2017). The IMO 2020 Sulphur Fuel Regulations aims to reduce the emission of sulfur oxides from ships. All ships have to use a fuel with sulphur content less than $0.5 \%$ from January 1, 2020.

Emission from merchant vessels when calling a port has much higher impact than those when sailing on high seas. The 5.4\% annual increase rate of the shipping trade in Asia corresponded to an average annual $5.9 \%$ increase of $\mathrm{SO}_{2}$

\footnotetext{
${ }^{*}$ Corresponding author.

E-mail address: tkliu@mail.ncku.edu.tw
}

emissions from shipping (Streets et al., 2000). The vesselsource air pollution has taken a toll on global coasts. A 2007 study based on limited data from 2001 found that global emissions from ocean going vessels (OGVs) were responsible for an estimated 60,000 premature deaths each year from cardiorespiratory disease and lung cancer (Corbett et al., 2007). The human health impact can result in chronic diseases or even damage the immune system (Dawson et al., 2001; Cropper et al., 2014; Maji et al., 2017; Lin et al., 2018; Wang et al., 2018; Hussain et al., 2019). In 2013, ship emissions led to more than 24,000 premature deaths in East Asia, with $18,000$ fatalities coming in mainland China alone ( $\mathrm{Su}, 2017)$. With better geospatial resolution data, Corbett et al. (2018) reported that annual shipping impact included $\sim 400,000$ premature deaths from lung cancer and cardiovascular disease and $\sim 14$ million childhood asthma cases annually. Even if low sulphur marine fuels is used, it still account for $\sim 250 \mathrm{k}$ deaths and $\sim 6.4 \mathrm{M}$ childhood asthma cases annually after 2018 (Sofiev et al., 2018).

$\mathrm{SO}_{2}$ is readily reacted with water and converted into acid rain, which is harmful to human health as well as infrastructure in coastal areas (Li et al., 2018). As a result, both the Baltic Sea and the North Sea areas established a sulfur emission control zone (SECA) in May 2006 and November 2007 (Volker et al., 2010). The United States established the ECA on August 1, 2012. Fuels with sulfur content less than $0.1 \% \mathrm{~m} / \mathrm{m}(1,000 \mathrm{ppm})$ must be used within 200 nautical miles of the US coast. For these SECA areas already in place, there is a cap of $0.1 \%$ sulphur in the fuel and a global sulphur limit of $0.5 \%$ outside the SECA 
starting from 2020. According to the third Greenhouse Gas (GHG) report released by IMO in 2014, $\mathrm{CO}_{2}$ emissions from international shipping activities in 2012 is 7,960 million tons, accounting for $2.2 \%$ of global emissions in the same year. Now there still remains no global $\mathrm{CO}_{2}$ limit clearly (EMSA, 2010). It is predicted that ship GHG emissions will increase by $50-250 \%$ between 2012 and 2050 (Smith et al., 2014). However, developing ports attract shipping traffic and form sources of concentrated exhaust emissions near populated areas (Lu et al., 2006). At the same time, Climate change is an example of an emerging global challenge with profound implications for ports, port cities and maritime transportation (U.S. EPA, 2009; Eyring et al., 2010; OECD, 2011).

To date three categories of measures have been discussed within the IMO to tackle GHG emissions from ships: technical measures, operational measures and market-based measures (MBMs) (Harilaos, 2012; IMO, 2014). These variables include vessel-source air pollution in different areas (harbor or ocean), type of vessel or vessel power, different types of consumed fuel oil, and differences in the cogitation of researchers (Corbett et al., 1997; Corbett et al., 2003; Maes, 2007; Faber, 2011). Theoretical methods are typically adopted to estimate the air pollution emissions generated by vessels in port areas. These methods are divided into fuelbased assessment and activity-based assessment according to activity intensity. The latter assessment is currently the most common method used to estimate vessel-source air pollution (Trozzi et al., 1995; Whall et al., 2002; Vangheluwe et al., 2007; Schrooten et al., 2008). In recent years, considerable efforts have been made and technological advancements have been achieved to improve the accuracy of ship emission estimates, such as on-board survey of fuel consumption and action (Song, 2014), and field-testing and reviewing of ship emission factors (Zhang et al., 2015).

The Port of Kaohsiung is one of the largest ports in Asia transporting international cargo and containers. The number of inbound and outbound vessels in the port and its cargo throughput are the highest in Taiwan, contributing to considerable emissions of air pollutants in Kaohsiung City. Although the tonnage of Taiwan-owned merchant fleets ranks $7^{\text {th }}$ in the world, with 3 shipping companies among the global top 20 leading service operators of container ships, but studies on the emissions of vessel-source pollutants are very limited. In this study, the vessel activity intensity method was adopted to estimate the emission of air pollutants from merchant vessels in the Port of Kaohsiung. The vessel activities were determined by using the vessel automatic identification system (AIS) to track vessel traffic and position and to calculate the corresponding emissions of air pollutants. It was demonstrated in Texas and the Netherlands that AIS data could also be used to quantify vessel operating hours and sailing positions through high-resolution vessel movement data, which in turn improve estimation of ship emissions during movements (Perez et al., 2009; MARIN, 2011). The AIS-based bottom-up methodology can be used for developing and upgrading ship emission inventory and formulating effective control measures on ship emissions in other port regions wherever possible through the study in
Pearl River Delta region (Cheng et al., 2016). In this study, the air pollutants quantified comprised $\mathrm{NO}_{x}, \mathrm{SO}_{\mathrm{x}}, \mathrm{PM}, \mathrm{CO}$, and HC. The results were then used to explore management strategies for controlling vessel-source emissions of air pollutants.

\section{METHODOLOGY}

\section{Study Area and Types of Vessels}

Taiwan is an island country, and its economic relies heavily on marine transportation. The port of Kaohsiung is the largest international port in Taiwan managed by Taiwan's International Port Company (TIPC). The port's own statistics show that in 2017 , nearly 18,773 vessels entered the port (TIPC, 2017). The study area was the Port of Kaohsiung with 123 existing terminals, 10.59 million TEUs in 2014 and in rank $13^{\text {th }}$ in global port container throughput (Lin, 2014). Because the Port of Kaohsiung has Taiwan's highest shipping volume, more research subjects and more complete shipping-related data can be obtained there. According to the Port of Kaohsiung Marine Traffic Service Operations Guide, the port includes a ship information service area with a range of $20 \mathrm{~nm}$ centered on $22^{\circ} 35^{\prime} \mathrm{N}$ and $120^{\circ} 17^{\prime} \mathrm{E}$. Merchant ships are vessels that engaged in commercial activities such as transporting cargo or passengers. We limited the research subjects to ocean-going vessels (OGVs) entering and leaving the Port of Kaohsiung and excluded fishing vessels, military ships, and special vessels. According to Kaohsiung Harbor Bureau, merchant vessel consists of containership, Cargo ship, bulk carrier, Oil tanker, Refrigerated ship, Passenger/cargo ship, Passenger ship, and others.

\section{Data Acquisition}

The ship data were divided into the basic data on the ships and dynamic ship data. The basic data on the ships comprised ship name, flag state, homeport, IMO, call number, gross tonnage, deadweight tonnage, net tonnage, breadth, length, and draft. We obtained these data from the classification societies of each nation and the official websites of the shipping companies. Dynamic ship data are the dynamic data on the ships' movements. Our main source for these data was the electronic archives of the vessel automatic identification system (AIS) provided by the Institute of Harbor and Maritime Technology, Ministry of Transportation and Communications. The AIS is a system that can receive and transmit radio information simultaneously. This radio information includes ship data, which can be divided into dynamic, static, and voyage data. The dynamic data comprise ship location, ground course, ground speed, heading, and navigational status.

Resolution MSC.99(73) compels all ships with gross tonnage over 300 on international routes, all cargo ships with gross tonnage over 500 on non-international routes, and all passenger ships of any size to install AIS equipment to increase the safety of maritime navigation and port security. In this study, we used the AIS data in the benchmarking of activity intensity to estimate air pollution emissions. The AIS data covered the entire range of Taiwanese waters. This study addresses only ships within a $20-\mathrm{nm}$ range of the Port 
of Kaohsiung. We used geographic information system (GIS) software to filter AIS data within 20-nm range of the Port of Kaohsiung. First, the raw AIS files were converted into comma-separated value (CSV) files. The CSV files were used to import the data into the GIS software. We used the vessel traffic service center for the Port of Kaohsiung as the center point to draw a $20-\mathrm{nm}$ range around the Port of Kaohsiung in the GIS software. This $20-\mathrm{nm}$ circle can also be used to filter data within this range, as shown in Fig. 1. The resulting data were then exported before finally being imported into a MySQL phpMyAdmin web server program to establish a complete database system.

This study had the following limitations: 1 . When processing the AIS data, we discovered missing and duplicated information. These errors had to be corrected through human judgment or condition setting to perform the emissions calculations. 2. The influence of ship- and weather-related factors should be avoided when interpreting AIS data. For example, during inclement weather, ship load may be maintained or increased, thereby affecting ship speed and causing the actual results to deviate from the estimated results. Regional winds, currents, and waves, such as the Kuroshio Current, the summer southwest monsoon, the winter northeast monsoon, and typhoons in Taiwan, also influence vessel traveling speed. Cargo deadweight and the amount of ballast water are closely associated with the propulsion capabilities of ships and directly affect ship fuel consumption. The above content was not within the scope of this study.

\section{Emission Estimation}

We referred the emission estimation formulae proposed by SCG (2011) and the IHMT (2012). Ship emissions come from the substantial amounts of air pollutants generated in the fuel combustion processes of ships' main engines, auxiliary engines, and auxiliary boilers. Therefore, the main engines, auxiliary engines, and auxiliary boilers of each ship are calculated separately. We divided the ship states into three stages: sailing, maneuvering, and hotelling.

The actual and maximum speeds of the ships were introduced into the load formula to calculate the extent of the loads in each ship. We used the loads to distinguish between the three ship states. Load over $20 \%$ defined the sailing state, under $20 \%$ the maneuvering state, and under $2 \%$ the hotelling state. Main engines, auxiliary engines, and auxiliary boilers emit different amounts of air pollutants depending on ship state. For example, auxiliary boilers operate and thus produce air pollutants only during the maneuvering and hotelling states, whereas main engines cannot operate during hotelling. Emissions were calculated as follows:

$$
\mathrm{E}(\text { emission })=\text { Energy } \times \mathrm{EF} \times \mathrm{FCF}
$$

$\mathrm{E}$ (emissions) is the emissions (grams) of the engines, Energy is the energy ( $\mathrm{kW}-\mathrm{h})$ generated by the combustion of fuel, EF (emission factor) is the emission factor (grams per

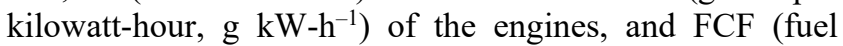
correction factor) is dimensionless. Eq. (1) uses the total energy produced by fuel combustion in the ship engines, auxiliary engines, and auxiliary boilers. This energy is converted into pollution emissions using the emission factor and the fuel correction factor. EF (emission factor) in Eq. (1) differs for the main engines, auxiliary engines, and auxiliary boilers. FCF is distinguished using the sulfur content of the fuel. Main engines, auxiliary engines, and auxiliary boilers primarily use either residual fuel with $2.7 \%$ sulfur content or marine diesel oil with 1.5\% sulfur content. Energy in Eq. (1) can be calculated using the following formula:

Energy $=\mathrm{MCR} \times \mathrm{LF} \times$ Act

MCR (maximum continuous rating) is the maximum kinetic energy ( $\mathrm{kW}$ ) used continuously by the engine, LF (load factor) is dimensionless, and Act (activity) is activity strength (hr). Eq. (2) primarily calculates the energy output of main engines. The main engines' MCR and LF within a unit of

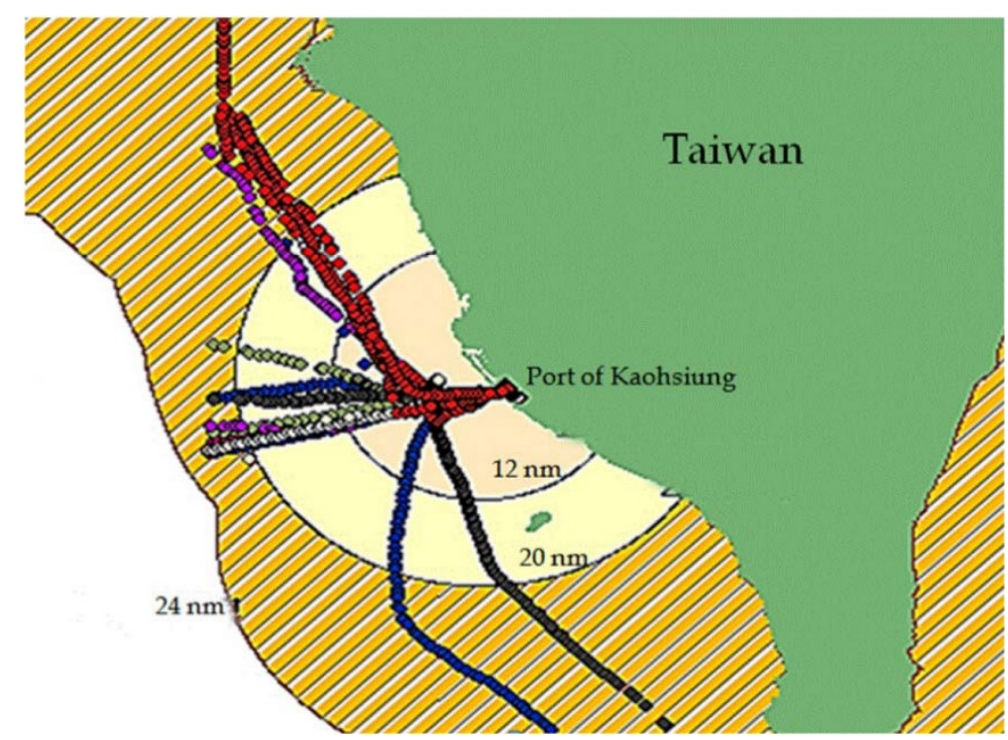

Fig. 1. Study area and the location of the $20-\mathrm{nm}$ circle for air pollution emission estimate in this study. 
time are multiplied by Act to calculate the energy output of the main engines. Additional calculations are performed for the energy output of the auxiliary engines and boilers. The sum of the energy output of the main engines, auxiliary engines, and auxiliary boilers is the overall energy output of the ship. Eq. (3) is used to calculate load factor (LF):

$$
\mathrm{LF}=(\mathrm{AS} / \mathrm{MS})^{3}
$$

AS is actual speed (knots). The ship speed in the AIS data is set to the actual ship speed. The maximum speed is MS. In Eq. (3), the actual speed in the AIS data is used to calculate the load factor of the main engines. Load factors between $20 \%$ and $80 \%$ are used to calculate emissions during ship sailing. When the load factor is under $20 \%$, corrected emission amounts must be calculated using the low-load adjustment multiplier (LLA).

\section{RESULTS AND DISCUSSIONS}

\section{Number of Vessels and Frequency of Visits}

We used phpMyAdmin to complete the ship list and then calculated the numbers of each type of vessel that appeared in the waters of the Port of Kaohsiung in 2013. Table 1 shows the results. A total of 6,561 ships appeared in the waters of the Port of Kaohsiung. Bulk carriers were the most numerous; the 2,225 bulk carriers constituted $33.9 \%$ of all ships. They were followed by 1,720 tankers, constituting $26.2 \%$ of all ships; 1,422 container ships, constituting $21.7 \%$ of all ships; and 1,052 cargo ships, constituting $16 \%$ of all ships. Refrigerated ships and ocean-going tugs were both approximately $1 \%$ of all ships. The number of passenger ships was the lowest at 21 . The statistics indicate that 3,335 ships entered the Port of Kaohsiung and 3,226 ships did not enter the port but only passed through its waters. The ships that entered the port and those that did not each constituted approximately half of all ships. We calculated ship trips by counting one trip each time a ship entered or departed from the Port of Kaohsiung. The AIS operates for long periods without interruption and must be kept activated even when hotelling. Thus, the AIS statistics should be continuous recordings without interruption. We assumed that the disappearance of a period of time in the AIS statistics indicated that a ship had left the waters of the Port of Kaohsiung. This was calculated as one ship trip. The estimated results indicated that ships entered and left the Port of Kaohsiung a total of 17,139 times in 2013.

\section{The Time Required for Three Modes of Inbound Vessel Operation}

The maritime sailing speeds of merchant speeds and their speeds when entering ports differ. In general, maritime sailing speed is maintained at between 15 and $25 \mathrm{kn}$. This speed is referred to as "sailing." When ships enter the regulatory range of the Port of Kaohsiung, they must cooperate with the demands of the traffic service center by lowering their speed to maintain ship navigation safety. Speed is typically maintained at less than $10 \mathrm{kn}$. This deceleration phase is referred to as "maneuvering". When ships dock at a pier, this is referred to as "hotelling". The speed of the ship approaches $0 \mathrm{kn}$ at this time. The effects of air current may result in slight movement. We calculated the average amount of time each type of ship spent sailing, maneuvering, and hotelling throughout the entirety of 2013. (See Table 2). When comparing sailing time, the results showed that the container ships spent a relatively long time sailing. Each ship spent an average of $31.3 \mathrm{hr}$ sailing throughout the year. The number of container ships and the amount of ship trips they took led to the average amount of time each ship spent sailing being relatively long. Bulk carriers spent the least amount of time sailing; each bulk carrier spent an average of $10.2 \mathrm{hr}$ sailing.

When comparing maneuvering time, the results showed that each tug spent an average of $21.7 \mathrm{hr}$ maneuvering throughout the year. This was the highest amount of time spent maneuvering. This may have been because tugs tend to operate at low speeds and thus ended up classified as being in the maneuvering state. Tugs are ships that provide service within harbors. Therefore, they spend particularly high amounts of time maneuvering and hotelling. The amount of time they spent hotelling was relatively high. Each tug spent an average of $385.7 \mathrm{hr}$ hotelling throughout the year. The long amounts of time the tugs spent within the port operating and hotelling led to the maneuvering and hotelling times being particularly long.

\section{Estimate of Air Pollutants Emitted}

We calculated the air pollutants emitted by each type of ship in the Port of Kaohsiung in 2013, covering emissions in the waters within $20 \mathrm{~nm}$ of the Port of Kaohsiung and

Table 1. The type and number of vessels in the study area and their frequency of calling.

\begin{tabular}{lllll}
\hline Type of vessel & $\begin{array}{l}\text { Number of vessels calling } \\
\text { the port of Kaohsiung }\end{array}$ & $\begin{array}{l}\text { Not calling the port of Kaohsiung } \\
\text { (innocent passage) }\end{array}$ & Total & $\begin{array}{l}\text { No. of visits in the } \\
\text { port of Kaohsiung }\end{array}$ \\
\hline Bulk & 813 & 1,412 & 2,225 & 2,502 \\
Cargo & 591 & 461 & 1,052 & 3,239 \\
Container & 857 & 565 & 1,422 & 6,245 \\
Passengers & 11 & 10 & 21 & 74 \\
Reefer & 54 & 18 & 72 & 289 \\
Tanker & 983 & 737 & 1,720 & 4,613 \\
Tug & 26 & 23 & 49 & 177 \\
Total & 3,335 & 3,226 & 6,521 & 17,139 \\
$\%$ & $51 \%$ & $49 \%$ & $100 \%$ & \\
\hline
\end{tabular}


including all ships that entered the port and those that passed through the waters outside of the port but did not enter. Fig. 2 shows the results.

Fig. 2 shows the ratios of the numbers of each type of ship and their emissions. These results indicate that although only $22 \%$ of all ships were container ships and the number of container ships was lower than the numbers of bulk carriers and tankers were, the substantial amounts of emissions they generated constituted more than half of all air pollutant emissions. They were the primary sources of pollutants among the ocean-going merchant ships in the Port of Kaohsiung. Tankers emitted the second-highest amount of pollutants. Ocean-going tugs, passenger ships, and refrigerated ships had the lowest emissions. From the perspective of ship speed, the container ships were faster than the other types of ships in terms of both maximum speed and maritime sailing speed. The same type of ship will require more kinetic energy and burn more fuel as its speed increases. This also increases pollution emissions. Thus, ship speed may be a factor in these results.

Since bulk carriers, container, and tanker are the main polluters, Fig. 3 shows the air pollutants from each sub-type of bulk carriers, container, and tanks, using emission of $\mathrm{SO}_{2}$ as an example. Bulk carriers were categorized into 4 sizes based on Baltic tonnage: 0 to 30,000 tons (handysize), 30,000 to 40,000 tons (handymax), 60,000 to 100,000 tons (panamax), and more than 100,000 tons (capesize). Fig. 3(a) shows the results. The handymax type had the highest number of ships and emissions, constituting 39\% of all bulk carriers. It was followed by the panamax type at $29 \%$. The handysize type had the fewest ships and constituted only $13 \%$ of the total. Fig. 3(b) shows the container ships that were classified into 10 ship sub-types from 1,000 TEU to
10,000 TEU, and the number of ships and emissions for each sub-type. The 1000-TEU container ships were the most numerous and constituted $28 \%$ of all container ships. They were followed by the 4,000-TEU container ships, which constituted $19 \%$ of the total. The 7,000-TEU container ships were the least numerous and constituted only $2 \%$ of the total. They were followed by the 9,000-TEU container ships, which were $3 \%$ of the total. The tankers were categorized into five types: handysize, panamax, aframax, VLCC (very large crude carrier), and ULCC (ultra large crude carrier). Fig. 3(c) shows these results. The majority of these ships were small tankers of the handysize type, which constituted $71 \%$ of all tankers. This was more than half of the total. The handysize tankers also had the highest emissions and were responsible for $66 \%$ of all tanker emissions. This was more than half of all emissions, making this type a primary source of pollution. The next most numerous type was ULCC. We also calculated the numbers of ships and emissions for the other types of ships; that is, the cargo ships, passenger ships, refrigerated ships, and tugs. These results indicate the presence of 1,052 cargo ships, constituting $16 \%$ of the total number of ships and 7\% of overall emissions. The oceangoing tugs and refrigerated ships were each only $1 \%$ of the total number of ships and the passenger ships constituted less than $1 \%$. These three types of ships were low in number. The emissions of the ocean-going tugs were less than $1 \%$ of total emissions.

Some of the ships entered the Port of Kaohsiung to berth, whereas others did not and merely pass through its coastal waters. The ships that entered the port emitted 10,268 tons of $\mathrm{SO}_{2}$. This was more than the 6,262 tons emitted by the ships that did not enter the harbor. Therefore, the ships that called the Port of Kaohsiung emitted more air pollutants

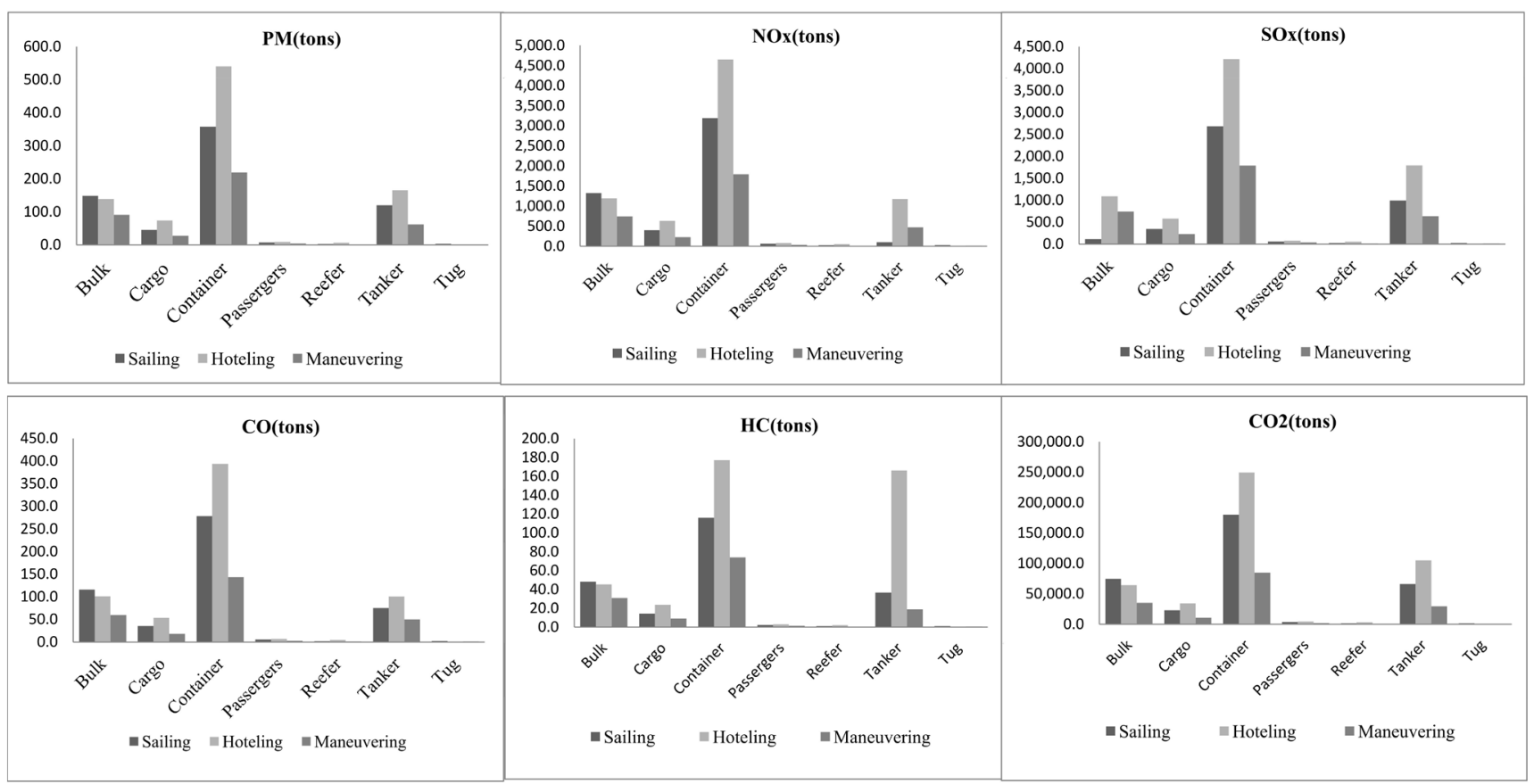

Fig. 2. The amount of air pollutants emitted for each type of inbound vessels and percentage of air pollutants in Kaohsiung city. 

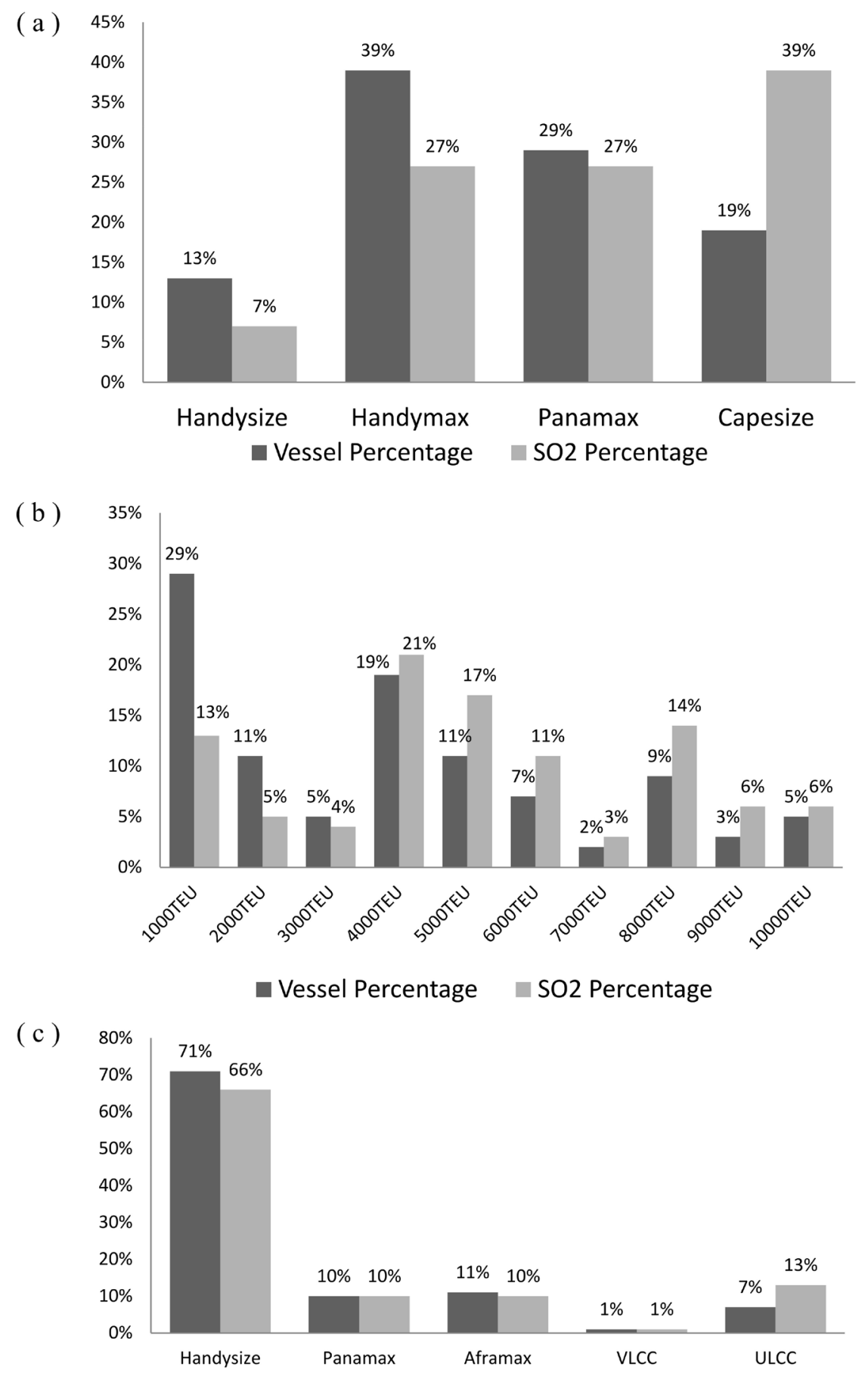

Fig. 3. Various type of vessels and their percentage of $\mathrm{SO}_{2}$ emission. (a) Bulk vessel; (b) Container; (c) Oil tanker.

than those that did not call the port. The total emission of $\mathrm{SO}_{2}$ from vessels, entering the port or merely passing by, is 16,530 tons. When compared to the $\mathrm{SO}_{2}$ emission in City of Kaohsiung, i.e., 37,849 tons in 2013, vessel source emission is equivalent to $43 \%$ of land-based emission in the City of Kaohsiung. Similarly, the vessel source emission of $\mathrm{NO}_{\mathrm{x}}$ and $\mathrm{PM}$ is equivalent to $23 \%$ and $9.4 \%$ of land-based emission. These ratios, i.e., vessel source to other source, are a little bit less than those in Hong Kong. Ship emissions were the largest emission source of $\mathrm{NO}_{\mathrm{x}}$ and $\mathrm{SO}_{2}$ emissions in Hong Kong in 2012, accounting for 32\% and 50\% of total emissions (Fung et al., 2014).

\section{MANAGEMENT STRATEGIES FOR VESSEL EMISSION CONTROL IN THE PORT OF KAOHSIUNG}

There are two global trends in the prevention of vesselsource air pollution. The first is a "command and control" approach requiring new legal instrument at national, regional, 
or global level, e.g., MARPOL Convention. The second is market-based tools providing incentives to encourage vessel owners to improve their technologies to meet with environmental standards (Liu et al., 2015; Kim et al., 2017). In this section, supplemental market-based policy tools are recommended based on our results and they are highlighted as follows.

\section{Green Navigation Measures}

According to the results in Fig. 2, vessels in hoteling state emit the greatest amount of air pollutant, followed by when in sailing state; vessels emit the least amount of air pollutants during maneuvering. The most effective way to directly reduce the emission for these vessels during hotelling state is to switch to shore power facilities while at berths (Liu et al., 2014). Similarly, for vessel approaching the port, entering with a reduced speed can greatly reduce the emission of air pollutant during the sailing state (Chang et al., 2013). Besides, adhering to the MARPOL Annex VI by switching to low sulfur fuel also help to reduce the emission of $\mathrm{SO}_{2}$. All these green navigation measures can mitigate the risk of health hazards caused by harmful air pollutants to the communities near the coastal area.

China's coastal area includes 7 of the top 10 container ports in the world, i.e., the ports of Shanghai, Shenzhen, Qingdao, Guangzhou, Ningbo, Tianjin, and Dalian (Wan et al., 2016). The Maritime Safety Administration of China (China MSA) announced that the Domestic Emission Control Area (DECA) within 12 nautical miles of the territorial sea was in effect since January 1, 2019 to enforce the use of lowsulfur fuel with a sulfur content of no more than $0.50 \%$ or approved equivalent methods. The port of Kaohsiung in Taiwan is the $13^{\text {th }}$ largest container port in the world. In 2018 , it provided incentives that a reward of 5,000 NTD was offered for vessels using low-sulfur oil (TIPC, 2018). Taiwan's Maritime Port Bureau later announced that it would be necessary to make the use of low-sulfur fuel oil or other approved equivalent methods mandatory for vessels calling Taiwan's commercial ports after January 1, 2019.

Since in past all these sulfur cap policies are only enforced within the commercial ports by Taiwan's law, it is recommended that amendments of the current Marine Pollution Control Act to adhere to regional or global standard to extend the enforcement to territorial sea. In the future, areas with serious air pollution can also be evaluated to adopt stricter IMO ECA standards of using fuel oil with sulfur content of $0.1 \%$. In order to mitigate vessel source air pollution, the TIPC encouraged ship owners to reduce the speed of ships in 2018. For containerships and cruise ships, 8,000 New Taiwan Dollars (NTD) was awarded for reducing the speed below 12 knots. About $45 \%$ of the vessels followed the incentive scheme when calling the port of Kaohsiung. A premium rate was provided to increase the ship owners' willingness to use the short power. In addition, the port of Kaohsiung currently has 17 low-voltage terminals and 7 highvoltage terminals with shore power connections. All of the port authorities owned harbor crafts were required to use shore power during standby period to help to reduce the emissions of air pollutants (TIPC, 2018).

\section{Trends in Eco-friendly Vessels Technology}

As the market and trade grow, subsequent port developments and shipping fleet expansion can not only affect natural ecosystems, but also impact the socio-economic environment (Carter et al., 2008; Gimenez et al., 2012; Schipper et al., 2015; Heaver, 2016; Xu et al., 2017). Emissions from ships engaged in international trade in the seas surrounding Europe - the Baltic Sea, the North Sea, the north-eastern part of the Atlantic, the Mediterranean and the Black Sea - were estimated at 2.3 million tonnes of sulphur dioxide $\left(\mathrm{SO}_{2}\right)$, 3.3 million tonnes of nitrogen oxides $\left(\mathrm{NO}_{\mathrm{x}}\right)$ in 2000 . Under a business as usual scenario, it is expected that shipping emissions of $\mathrm{SO}_{2}$ and $\mathrm{NO}_{\mathrm{x}}$ will increase by $40 \%-50 \%$ between the year 2000 and 2020 (Cofala et al., 2018).

Most of the research studies on vessel-source pollution have focused on finding the relationship between pollutants emission and mitigation measures such as port facilities improvement and green shipping (Yuen et al., 2016; Yang, 2017; Yuen et al., 2017). Currently, eco-friendly vessels are green vessels that meet the IMO Conventions, which came into force in accordance with regulations published by the IMO (Lee et al., 2017). The introduction of eco-friendly vessels is necessary in order to meet the environmental regulations of international ports and ports in developed countries as well as to handle the replacement of bunker oil, which involves high uncertainty and represents the largest portion of operating costs in the shipping industry (Yang, 2012). The shipbuilding and shipping industry is taking the lead in building eco-friendly vessels that reduce fuel consumption, thereby maximizing fuel efficiency by replacing existing ships that have difficulty competing in terms of cost and that cannot meet environmental standards (Schroten et al., 2011; Kim, 2015; Tran et al., 2016).

Table 2 shows the results that ship's emissions of $\mathrm{SO}_{2}$ and $\mathrm{NO}_{x}$ are relatively high compared to those from the emissions from the City of Kaohsiung. Unlike $\mathrm{NO}_{\mathrm{x}}$ emissions can be abated by main engine design and operation adjustment; sulfur emissions reduction requires using low sulfur fuel or other equivalent means. Since the low sulfur limit of MARPOL Annex VI will apply on and after January 1, 2020, it will force shipowners to switch to high-priced fuel oil such as light diesel oil (MGO) and ultra-low sulfur fuel oil (ULSFO). Technology related to emission reduction also help shipping sector to meet Annex VI compliance requirement. With the advancement of shipbuilding technology, most of the technologies available for ecofriendly vessels now include: (1) Installation of a scrubber instead of burning low-sulfur fuel (Panasiuk et al., 2015). Although scrubbers may be expensive now, the costs will go down as the demand for scrubbers go up and production scales; (2) Modification of the main engine for exhaust gas recirculation (Lamas et al., 2012). In this way, oxygen content of the intake air can be reduced. The high heat content of water vapor and carbon dioxide in the exhaust gas can help to lower the combustion temperature, thus reducing the NOx formation; (3) Use liquefied natural gas (LNG) as a fuel booster (Knigsson et al., 2011; IMO, 2016). Since LNG does not have sulfur residues, it can be used on ships to reduce emissions of $90 \%$ of nitrogen oxides, $100 \%$ of 
Table 2. The average amount of time each type of inbound vessels spent according to their ship state in the port of Kaohsiung.

\begin{tabular}{lllllll}
\hline \multirow{2}{*}{ Type of vessel } & \multicolumn{5}{c}{ Ship states and average time spend } \\
\cline { 2 - 7 } & Sailing & Ave $(\mathrm{hr})$ & Maneuvering & Ave (hr) & Hotelling & Ave (hr) \\
\hline Bulk & 22654.9 & 10.2 & 3963.6 & 1.8 & 95276.3 & 42.8 \\
Cargo & 19534.3 & 18.6 & 5085.4 & 4.8 & 113752.8 & 108.1 \\
Container & 44506.6 & 31.3 & 10898.8 & 7.7 & 125071.2 & 88.0 \\
Passengers & 280.2 & 13.3 & 42.0 & 2.0 & 1189.6 & 56.6 \\
Reefer & 969.6 & 13.5 & 271.0 & 3.8 & 18264.1 & 253.7 \\
Tanker & 27448.8 & 16.0 & 10076.1 & 5.9 & 178691.3 & 103.9 \\
Tug & 627.1 & 12.8 & 1063.2 & 21.7 & 18898.2 & 385.7 \\
Total & 116021.5 & 17.7 & 31399.9 & 4.8 & 551143.4 & 84.0 \\
\hline
\end{tabular}

sulfur oxides, $25 \%$ of suspended solids and $25 \%$ of carbon dioxide. Due to the advent of energy-saving and zeropollution technologies, eco-friendly vessels have also been adopted by a large number of vessel owners.

\section{Policy Implications in Taiwan}

In the past, the TIPC implemented an incentive program to reduce vessel speed and encourage the use of low-sulfur fuels. On January 1, 2019, it was mandatory to switch to the $0.5 \%$ sulphur fuel when entering the commercial port. Violators will be charged a penalty of 100,000 and 500,000 NTD. It is recommended that these penalties collected for non-compliance can serve as an air pollution mitigation fund for pollution prevention, port maintenance, and installation of shore power facilities. The use of economic means to reduce emissions of air pollution is a useful tool for controlling landbased emissions or vessel source emission in various countries in recent years. Currently, several economic tools are used for mitigating air pollution in ports, including rate discounts for switching fuel oils to marine distillates, and fairway and port dues for maritime shipping (Liu et al., 2014). The Taiwan's Ministry of Transportation and Communications and the Environmental Protection Agency should work jointly to set up an incentive mechanism to encourage ships to implement these market-based tools. For example, in addition to the industry-led green shipping incentive programs, Norway and Sweden have implemented national incentive programs to encourage the adoption of green marine fuel, technologies, and operational practices (Becque et al., 2017). Norwegian-registered vessels are required to pay tax calculated on the basis of actual $\mathrm{NO}_{\mathrm{x}}$ emissions (IACCSEA, 2015). The $\mathrm{NO}_{\mathrm{x}}$ Fund has been a main driver for the use of $\mathrm{LNG}$ and $\mathrm{NO}_{\mathrm{x}}$ after-treatment technologies in the marine sector in Norway. The Swedish program is to use differentiated fairway dues to encourage the reduction of emissions of $\mathrm{SO}_{\mathrm{x}}$ and $\mathrm{NO}_{\mathrm{x}}$ from shipping in Swedish fairways and ports (ICCT, 2007).

LNG seemed to be a choice to meet more stringent environmental regulations and the availability of using it as a bunker fuel continued to grow. The calorific value per ton of LNG is comparable to that per ton of fuel oil, but the price is more attractive for achieving the goal of environmental protection and green shipping. LNG is expected to gain a more favorable position as an alternative for marine fuel for complying with the global sulphur cap (DNV.GL, 2019). Existing LNG bunkering infrastructure focused mainly in the Baltic, North Sea, and some limited ports in North America. Ports in the Asia-Pacific region such as in Korea, China, Japan, and Singapore also offers LNG bunkering or plans to do so in the coming years. Currently, Taiwan lacked of LNG bunkering infrastructure and it is feared that it will reduce the competitiveness with other international ports. Since LNG fuel is bound to become an important marine fuel under the global trend of green shipping, it is recommended that TIPC needs to increase LNG availability in all international commercial port to ensure the competitive position.

\section{CONCLUSION}

In this study, we used AIS statistics of the ships to estimate the pollution emissions of merchant ships in the Port of Kaohsiung. The air pollution control strategy from the ports around the world were also explored to promote port air pollution controls in Taiwan in the future. Among these vessels, container ships emitted more air pollutants than bulk carriers and oil tankers, although the numbers of bulk carriers and oil tankers were greater than the number of container ships. These three types of vessel were the main polluters, generating approximately $90 \%$ of the total air pollutants. The emissions of air pollutants for these vessels were estimated to be 10,268 tons and 10,324 tons for $\mathrm{SO}_{2}$ and $\mathrm{NO}_{\mathrm{x}}$, respectively. The contributions of emissions during sailing, maneuvering, and hotelling were estimated to be $32.1 \%, 20.5 \%$, and $47.3 \%$, respectively. Hotelling generated the most $\mathrm{SO}_{2}$ emissions, 7825.5 tons, of the three ship states; this was $47.3 \%$ of $\mathrm{SO}_{2}$ total emissions. Since vessels emit the most air pollutants when hotelling, the most direct method for reducing emissions would be for ships to switch to low-sulfur fuel oils or even using shore power while hoteling. In conjunction with MARPOL's implementation of low-sulfur fuel regulations, the ship owners started to install scrubbers to meet compliance, while shipyards develop vessels powered by LNG. On the other hand, it is necessary for TIPC to continue to increase or upgrade air pollution mitigation facilities such as shore power and LNG bunkering infrastructure, as well as to pursue market-based tools that provides incentives for further reduction of air pollutants.

\section{ACKNOWLEDGMENT}

The authors would like to express sincere thanks to the people from Kaohsiung Port Company for their help in 
providing assistance and the vessel transit information. The opinions expressed therein are of the authors only and any error remains the sole responsibility of the authors. The research was partially funded by College of Engineering, National Cheng Kung University, Taiwan.

\section{REFERENCE}

Baltcher, D.J. and Eames, I. (2013). Compliance of Royal Navy ships with nitrogen oxide emissions legislation. Mar. Pollut. Bull. 74: 10-18.

Becque, R., Fung, F. and Zhu, Z. (2017). Incentive schemes for promoting green shipping. The Natural Resources Defense Council (NRDC), New York, the United States of America (USA).

Butterfield, D.M. and Quincey, P. (2017). An investigation into the effects of off-shore shipping emissions on coastal black carbon concentrations. Aerosol Air Qual. Res. 17: 218-229.

Carter, C.R. and Rogers, D.S. (2008). A framework of sustainable supply chain management: Moving toward new theory. Int. J. Phys. Distrib. Logist. Manage. 38: 360-387.

Chang, C.C. and Chang, C.H. (2013). Energy conservation for international dry bulk carriers via vessel speed reduction. Energy Policy 59: 710-715.

Cofala, J., Amann, M., Borken-Kleefeld, J., Gomez-Sanabria, A., Heyes, C., Kiesewetter, G., Sander, R., Schoepp, W., Holland, M., Fagerli, H. and Nyiri, A. (2018). The potential for cost-effective air emission reductions from international shipping through designation of further Emission Control Areas in EU waters with focus on the Mediterranean Sea. International Institute for Applied System Analysis (IIASA), Vienna, Austria.

Corbett, J.J. and Fischbeck, P. (1997). Emissions from ships. Science 278: 823-824.

Corbett, J.J. and Koehler, H.W. (2003). Updated emissions from ocean shipping, J. Geophys. Res. 108: 46-50.

Corbett, J.J., Winebrake, J.J., Green, E.H., Kasibhatla, P., Eyring, V. and Lauer, A. (2007). Mortality from ship emissions: A global assessment. Environ. Sci. Technol. 41: 8512-8518.

Corpper, M. and Khanna, S. (2014). How should the World Bank estimate air pollution damages? Discussion paper, Resources for the future. Washington, DC, the United States of America (USA).

Dawson, S.V. and Alexeeff, G.V. (2001). Multi-stage model estimates of lung cancer risk from exposure to diesel exhaust, based on cohort study of U.S. railroad workers. Risk Anal. 21: 1-18.

DNV.GL (2019). Global sulphur cap 2020-Compliance options and implications for shipping focus on scrubbers. Det Norske Veritas Germanischer Lloyd (DNV.GL) Maritime 02/2019, Oslo, Norway.

European Maritime Safety Agency (2010). The 0.1\% sulphur in fuel requirement as from 1 January 2015 in SECAs-An assessment of available impact studies and alternative means of compliance. Lisbon, Portugal.

Eyring, V., Isaksen, I.S.A., Berntsen, T.B., Collins, W.J.,
Corbett, J.J., Endresen, O., Grainger, R. G., Moldanova, J., Schlager, H. and Stevenson, D.S. (2009). Transport impacts on atmosphere and climate: Shipping. Atmos. Environ. 44: 4735-4771.

Faber, J., Behrends, B. and Nelissen, D. (2011). Analysis of GHG marginal abatement cost curves. CE Delft. Delft, Netherlands.

Fung, F., Zhu, Z., Renidle, B. and Barbara, F. (2014). Prevention and control of shipping and port air emission in China. The Natural Resources Defense Council (NRDC), New York, the United States of America (USA).

Gimenez, C., Sierra, V. and Rodon, J. (2012). Sustainable operations: Their impact on the triple bottom line. Int. J. Prod. Econ. 140: 149-159.

Harilaos, N. (2012). Market-based measures for greenhouse gas emissions from ships: A review. WMU J. Marit. Affairs 11: 211-232.

Heaver, T. (2016). The evolution and challenges of port economics. In Devolution, port governance and port performance. Brooks, M.R. and Cullinane, K. (Eds.), Elsevier Ltd., pp. 11-41.

Hussain, R. and Luo, K. (2019). The geological availability and emissions of sulfur and $\mathrm{SO}_{2}$ from the typical coal of China. Aerosol Air Qual. Res. 19: 559-570.

IACCSEA (2015). Marine $\mathrm{NO}_{\mathrm{x}}$ regulation, taxes and incentive schemes. The International Association for Catalytic Control of Ship Emissions to Air (IACCSEA), London, United Kingdom.

ICCT (2007). Air pollution and greenhouse gas from oceangoing ships: impacts, mitigation options and opportunities for managing growth. International Council on Clean Transportation (ICCT), San Francisco, California, the United States of America (USA).

IHMT (2012). Study on the carbon abatement in Taiwan's commercial ports. Institute of Harbor and Marine Technology (IHMT), Taichung, Taiwan.

Im, J., Lee, E., Kim, C., Kim, J., Choi, J. and Kim, E. (2005). Green shipping outlook and response strategy. Korea Maritime Institute, Busan, South Korea.

IMO (2010). MARPOL Annex VI. International Maritime Organization (IMO), London, United Kingdom.

IMO (2011). Main events in IMO's work on limitation and reduction of greenhouse gas emissions from international shipping. International Maritime Organization (IMO), London, United Kingdom.

IMO (2014). Third IMO GHG study. International Maritime Organization (IMO), London, United Kingdom.

IMO (2016). Air pollution and energy efficiency-assessment of fuel oil availability - final report, MEPC 70/INF.6. International Maritime Organization (IMO), London, United Kingdom.

Kim, S. (2015). Korea's shipbuilding industry, jump into eco-friendly ship research. Green Technology Center (GTC), Seoul, South Korea.

Kim, Y.P. and Lee, G. (2018). Trend of air quality in Seoul: Policy and science. Aerosol Air Qual. Res. 18: 2141-2156.

Konigsson, F., Stalhammar, P. and Angstrom, H. (2011). Characterization and potential of dual fuel combustion in a modern diesel engine. Society of Automotive Engineers 
(SAE) international technical paper. Pittsburgh, the United States of America (USA).

Lai, H.K., Tsang, H., Chau, J., Lee, C.H., McGhee, S.M., Hedley, A.J. and Wong, C.M. (2012). Health impact assessment of marine emissions in Pearl River Delta region. Mar. Pollut. Bull. 66: 158-163.

Lamas, M.I. and Rodríguez C.G. (2012). Emissions from marine engines and $\mathrm{NO}_{\mathrm{x}}$ reduction methods. J. Mar. Res. 9: 77-82.

Lee, T. and Nam, H. (2017). A study on green shipping in major countries: in the view of shipyards, shipping companies, ports, and policies. Asian J. Shipping Logist. 33: 253-262.

Li, C., Yuan, Z., Ou, J., Fan, X., Ye, S., Xiao, T., Shi, Y., Huang, Z., Ng, S.K.W., Zhong, Z. and Zheng, J. (2016). An AIS-based high-resolution ship emission inventory and its uncertainty in Pearl River Delta region. China. Sci. Total Environ. 573: 1-10.

Li, Z., Hu, Y.H., Chen, L., Wang, L., Fu, D., Ma, H., Fan, L., An, C. and Liu, A. (2018). Emission factors of $\mathrm{NO}_{\mathrm{x}}$, $\mathrm{SO}_{2}$, and $\mathrm{PM}$ for bathing, heating, power generation, coking, and cement industries in Shanxi, China: Based on field measurement. Aerosol Air Qual. Res. 18: 31153126.

Li, Z., Wang, Y., Hu, Y., Chen, L. and Zhu, H. (2019). Emissions of $\mathrm{NO}_{\mathrm{x}}, \mathrm{PM}, \mathrm{SO}_{2}$, and $\mathrm{VOC}_{\mathrm{s}}$ from coal-fired boilers related to coal washing, iron-steel production, and lime and gypsum making in Shanxi, China. Aerosol Air Qual. Res. 19: 2056-2069.

Lin, N.H., Chang, M.B., Hwang, J., Kaneyasu, N. and Zhang, R. (2018). Overview of the special issue "Aerosol source, transport, chemistry, and emission control" for the $10^{\text {th }}$ Asian aerosol conference 2017. Aerosol Air Qual. Res. 18: 1515-1518.

Lin, S.R. (2014). The promoting strategy of green ports. Ph.D. thesis, Department of Transportation \& Logistics Management College of Management, National Chiao Tung University, Taiwan (in Chinese).

Lister, J., Taudal, P.R. and Ponte, S. (2015). Orchestrating transnational environmental governance in maritime shipping. Global Environ. 34: 185-195.

Liu, T.K., Sheu, H.Y. and Tsai, J.Y. (2014). Sulfur dioxide emission estimate from merchant vessels in a port area and its control strategies. Aerosol Air Qual. Res. 14: 413421.

Liu, T.K., Kao, J.C. and Chen, P. (2015). Tragedy of the unwanted commons: Governing the marine debris in Taiwan's oyster farming. Mar. Policy 53: 123-130.

Lu, G., Brook, J.R., Alfarra, M.R., Anlauf, K., Leaitch, W.R. and Sharma, S. (2006). Identification and characterization of inland ship plumes over Vancouver, BC. Atmos. Environ. 40: 2767-2782.

Lun, Y.V., Lai, K.H., Wong, C.W. and Cheng, T.E. (2015). Greening and performance relativity: An application in the shipping industry. Comput. Oper. Res. 54: 295-301.

Maes, F., Vanhaecke, P. and Ypersele, J.P. (2007). Emissions of $\mathrm{CO}_{2}, \mathrm{SO}_{2}$ and $\mathrm{NO}_{\mathrm{x}}$ from Ships. Scientific Support Plan for a Sustainable Development Policy. Belgian Science Policy (BELSPO). Brussels, Belgium.
Maji, K.J., Dikshit, A.K. and Deshpanda, A. (2017). Assessment of city level human health impact and corresponding monetary cost burden due to air pollution in India taking Agra as a model city. Aerosol Air Qual. Res. 17: 831-842.

MARIN (2010). Emissions 2008: Netherlands continental shelf, port areas and OSPAR Region II. Ordered by Netherlands Environmental Assessment Agency, Wageningen, Netherlands.

MARIN (2011). Emissions 2009: Netherlands continental shelf, port areas and OSPAR Region II. Ordered by Netherlands Environmental Assessment Agency, Wageningen, Netherlands.

Matthias, V., Bewersdorff, I., Aulinger, A. and Quante, M. (2010). The contribution of ship emissions to air pollution in the North Sea regions. Environ. Pollut. 158: 22412250.

OECD (2011). Environmental Impacts of international shipping: The role of ports. OECD Publishing, Paris, France.

Panasiuk, I. and Turkina, L. (2015). The evaluation of investments efficiency of $\mathrm{SO}_{\mathrm{x}}$ scrubber installation. Transp. Res. D 40: 87-96.

Perez, H.M., Chang, R., Billings, R. and Kosub, T.L. (2009). Automatic identification systems (AIS) data use in marine vessel emission estimation. Paper Presented at the $18^{\text {th }}$ Annual International Emission Inventory Conference, Baltimore, Maryland.

SCG (2011). Port of Long Beach air emissions inventory 2011. Long Beach, CA. Starcrest Consulting Group (SCG), Long Beach, the United States of America (USA).

Schipper, C.A., Vergouwen, S., Bel de, B. and Jong, M. (2015). Ports of the future. Exploratory study. Deltares report 1220137-000 45. Delft, Netherlands.

Schrooten, L., Vlieger, I.D., Panis, L.I., Styns, K. and Torfs, R. (2008). Inventory and forecasting of maritime emissions in the Belgian Sea territory, an activity-based emission model. Atmos. Environ. 42: 667-676.

Schroten, A., Van Essen, H. and Anthes, R. (2011). External cost calculator-methodology report. CE Delft and IVE $\mathrm{mbH}$. Delft, Netherlands.

Smith, T.W.P., Day, S., Bucknall, R., Mangan, J., Dinwoodie, J., Landamore, M., Turan, O. and Wrobel, P. (2013). Low carbon shipping - A systems approach. Final report. Newcastle University, United Kingdom.

Smith, T.W.P., Jalkanen, J.P., Anderson, B.A., Corbett, J.J. and Faber, J. (2014). Third IMO GHG study. International Maritime Organization, London, United Kingdom.

Sofiev, M., Winebrake, J.J., Johansson, L., Carr, E.W., Prank, M., Soares, J., Vira, J., Kouznetsov, R., Jalkanen, J.P. and Corbett, J. (2018). Cleaner fuels for ships provide public health benefits with climate tradeoffs. Nat. Commun. 9: 406.

Song, S. (2014). Ship emissions inventory, social cost and eco-efficiency in Shanghai Yangshan port. Atmos. Environ. 82: 288-297.

Streets, D.G., Guttikunda, S.K. and Carmichael, G.R. (2000). The growing contribution of sulfur emissions from ships in Asian waters. Atmos. Environ. 34: 4425-39. 
$\mathrm{Su}$, S. (2017). A clean air challenge for China's ports: Cutting maritime emissions. World Resources Institute, Beijing, China.

TIPC (2014). Port of Kaohsiung environmental report 2014. Taiwan International Ports Corporation (TIPC), Kaohsiung city, Taiwan.

TIPC (2017). Taiwan inbound vessels and gross tonnage annual report. Taiwan International Ports Corporation (TIPC), Kaohsiung city, Taiwan.

TIPC (2018). Port of Kaohsiung environmental report 2018. Taiwan International Ports Corporation (TIPC), Kaohsiung city, Taiwan.

Trozzi, C., Vaccaro, R. and Nicolo, L. (1995). Air pollutants emissions estimate from maritime traffic in the Italian harbours of Venice and Piombino. Sci. Total Environ. 169: 257-263.

U.S. EPA (2004). Proposal to designate an emission control area for nitrogen oxides, sulfur oxides and particulate matter, technical support document. Chapter 2 emission inventory. Assessment and Standards Division, Office of Transport and Air Quality, United States EPA.

Vangheluwe, M., Mees, J. and Janssen, C. (2007). Monitoring program on air pollution from sea-going vessels. Scientific Support Plan for a Sustainable Development Policy, Belgian Science Policy (BELSPO). Brussels, Belgium.

Wang, W., Chi, K., Zhao, R., Hsieh, L.T. and Lee, W.J. (2018). Characterization of the air quality index for Wuhu and Bengbu Cities, China. Aerosol Air Qual. Res. 18: 1198-1220.

Whall, C., Cooper, D., Archer, K., Twigger, L., Thurston, N., Ockwell, D., McIntyre, A. and Ritchie, A. (2002). Quantification of emissions from ships associated with ship movements between ports in The European community.
European Commission, Entec UK Limited.

Xu, J., Jiang, H., Zhao, H. and Stephens, B. (2017). Mobile monitoring of personal $\mathrm{NO}_{\mathrm{x}}$ exposures during scripted daily activities in Chicago, IL. Aerosol Air Qual. Res. 17: 1999-2009.

Xu, T., Chen, H., Lu, X., Gross, D.S., Yang, X., Mo, Z., Chen, Z., Liu, H., Mao, J. and Liang, G. (2017). Singleparticle characterizations of ambient aerosols during a wintertime pollution episode in Nanning: local emissions vs. regional transport. Aerosol Air Qual. Res. 17: 49-58.

Yang, C.S. (2017). An analysis of institutional pressures, green supply chain management, and green performance in the container shipping context. Transp. Res. D 61:246260

Yang, J. (2012). Green ship - New challenges and opportunities in shipbuilding industry. Export - Import Bank of Korea. Seoul, South Korea.

Yuen, K.F. and Lim, J.M. (2016). Barriers to the implementation of strategic corporate social responsibility in shipping. Asian J. Shipping Logist. 32: 49-57.

Yuen, K.F., Wang, X., Wong, Y.D. and Zhou, Q. (2017). Antecedents and outcomes of sustainable shipping practices: the integration of stakeholder and behavioral theories. Transp. Res. E 108: 18-35.

Zhang, F., Chen, Y., Tian, C., Li, J., Zhang, G. and Matthias, V. (2015). Emissions factors for gaseous and particulate pollutants from offshore diesel engine vessels in China. Atmos. Chem. Phys. 15: 1-35.

Received for review, July 20, 2019 Revised, September 16, 2019 Accepted, September 17, 2019 